Published as: Abell, J. M., Hamilton, D. P. \& Paterson, J. (2011) Reducing the external environmental costs of pastoral farming in New Zealand: experiences from the Te Arawa lakes, Rotorua. Australasian Journal of

Environmental Management, 18 (3), 139-154. Available at: http://dx.doi.org/10.1080/14486563.2011.591520

\title{
Reducing the external environmental costs of pastoral farming in New Zealand: experiences from the Te Arawa lakes, Rotorua
}

\section{Authors:}

Jonathan M. Abell ${ }^{\mathrm{A} *}$, David P. Hamilton ${ }^{\mathrm{A}}$ and John Paterson ${ }^{\mathrm{B}}$

${ }^{\text {A }}$ Centre for Biodiversity and Ecology Research, University of Waikato, Private Bag 3105, Hamilton 3240, New Zealand.

${ }^{B}$ Bay of Plenty Regional Council, P.O. Box 364, Whakatane, 3158, New Zealand

*Corresponding author. Tel.: +64 7858 5046, Fax: +64 7838 4324. E-mail address: jma27@waikato.ac.nz

Keywords: agriculture, eutrophication, lake restoration, nutrients, policy, water quality

\begin{abstract}
Decades of nutrient pollution have caused water quality to decline in the nationally iconic Te Arawa (Rotorua) lakes in New Zealand. Pastoral agriculture is a major nutrient source and therefore this degradation represents an external environmental cost to intensive farming. This cost is borne by the wider community and a major publically-funded remediation programme is now underway. This article describes the range of actions being taken to reduce nutrient loads from internal (lake bed sediments) and external (primarily diffuse) sources in the lake catchments. The high economic cost and uncertain efficacy of engineering-based actions to reduce internal nutrient loads is highlighted. Major changes to land management practices to control diffuse nutrient pollution are required throughout New Zealand if the need for costly and lengthy remediation programmes elsewhere is to be avoided. More action to educate farmers and the public about eutrophication issues, development and enforcement of environmental standards, and further consideration of the use of market-based instruments are proposed as ways to correct the current market failure.
\end{abstract}


Published as: Abell, J. M., Hamilton, D. P. \& Paterson, J. (2011) Reducing the external environmental costs of pastoral farming in New Zealand: experiences from the Te Arawa lakes, Rotorua. Australasian Journal of Environmental Management, 18 (3), 139-154. Available at: http://dx.doi.org/10.1080/14486563.2011.591520

\section{Introduction}

New Zealand is renowned for being 'clean and green', a concept that is an important part of the country's competitive advantage in several core industries and part of the national marketing strategy for tourism. The activities of the country's largest primary industry, namely agriculture (New Zealand Treasury 2009), do not, however, always complement this reputation. Pastoral agriculture, particularly dairy farming, has intensified over the last few decades: the national dairy herd increased by approximately $82 \%$ between 1980 and 2009 to nearly six million cows (Figure 1). This intensification has contributed to the decline of several essential ecosystem services including the provision of good quality freshwater (PCE 2004; Baskaran et al. 2009). As a result, declining freshwater quality is now a critical issue in New Zealand (Land and Water Forum 2010); improving the management of the country's water resources has become a government priority (MfE 2009).

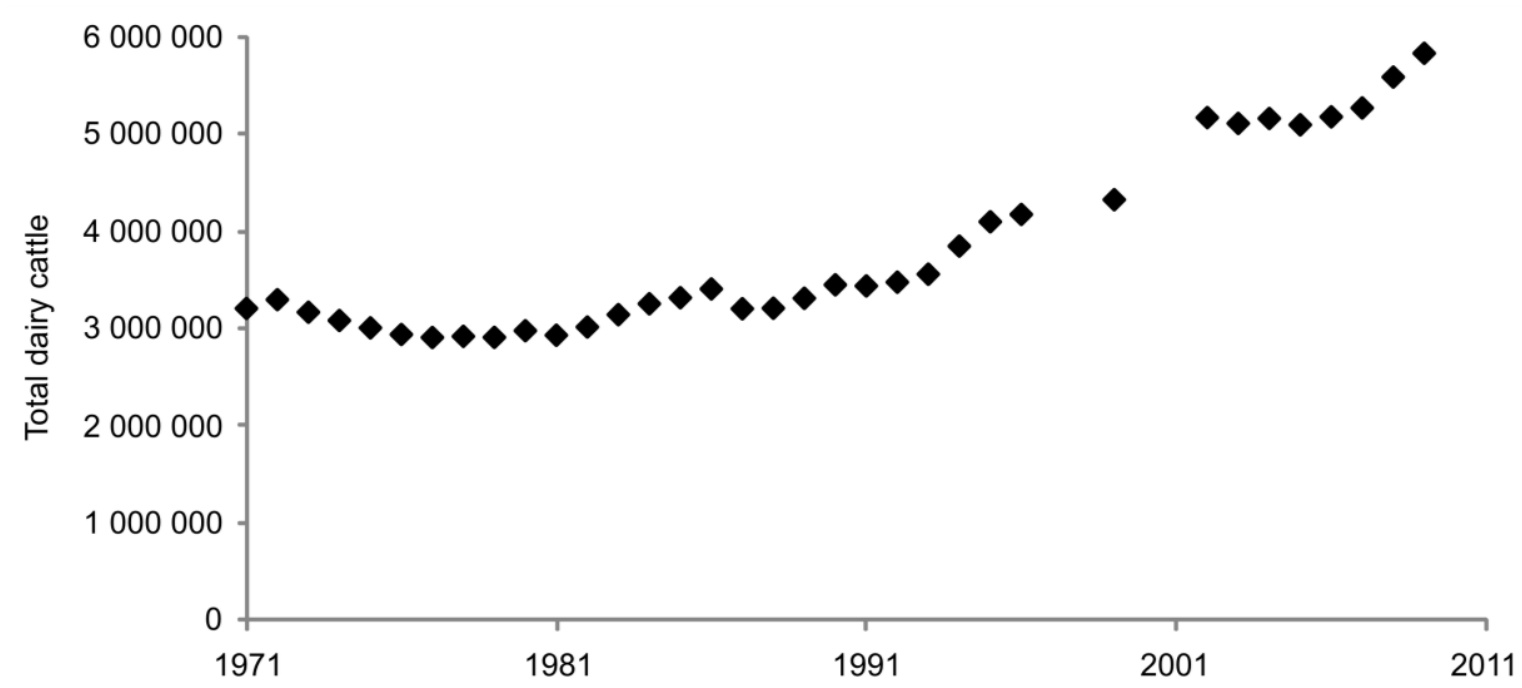

Figure 1 Total dairy cattle in New Zealand 1980-2009. Note that the calculation method was changed in 2002 (Statistics New Zealand, 2009).

A major cause of water quality decline in New Zealand is the anthropogenic eutrophication of streams and lakes caused by excess nutrient inputs, primarily nitrogen and phosphorus, from agricultural sources (PCE 2004; Abell et al. 2011). In this respect, the intensification of the dairy industry is of particular concern as median nutrient loads from dairy farms have been shown to be significantly higher than from other pastoral land uses such as sheep farming (McDowell \& Wilcock 2008). The main sources of nutrients to waterbodies from New Zealand grazing systems are nitrate leached from animal excreta (particularly urine), while 
Published as: Abell, J. M., Hamilton, D. P. \& Paterson, J. (2011) Reducing the external environmental costs of pastoral farming in New Zealand: experiences from the Te Arawa lakes, Rotorua. Australasian Journal of

Environmental Management, 18 (3), 139-154. Available at: http://dx.doi.org/10.1080/14486563.2011.591520

phosphorus is typically associated with eroded soil particles transported by surface runoff (PCE 2004; McDowell \& Wilcock 2008). Elevated nutrient concentrations in freshwaters can cause undesirable growth of algae, resulting in unsightly, odorous and potentially toxic blooms, along with an overall decline in ecological health (Smith et al. 1999). The challenges to maintaining and improving New Zealand's water quality represent a microcosm of the global situation, and predicted climate change is expected to result in both an increase in nutrient loads and an enhanced sensitivity of inland waters to nutrient pollution, thereby exacerbating the problem (Jeppesen et al. 2011).

The anthropogenic eutrophication in predominantly agricultural catchments in New Zealand is an archetypal example of the 'Tragedy of the Commons' (Hardin 1968). Hardin's original analogy focused on the inevitability of overgrazing to occur when herdsmen are allowed to graze their stock on common land. As he acknowledged, the concept applies equally to the pollution of common resources such as air, or in this case, freshwater, whereby polluters (e.g. farmers) are only burdened with an individual cost from polluting a common resource that is much smaller than the cost of adequately treating or eliminating their waste.

The developing field of ecological economics allows the degradation of common resources to be viewed in terms of a reduction to the value of ecosystem services as a result of the externalisation of environmental costs associated with production activities (Lant et al. 2008). Ecosystem services are derived from ecosystem functions and include climate regulation, soil formation and erosion control (Costanza et al. 1997). In this case, the common resource in question is fresh water and the external environmental costs of agricultural production include a decline in recreational opportunities, reduced landscape and visual values and the constraints on supply of, or additional treatment requirements for, drinking water. The cost is external because individual farmers usually bear only a small share of the costs (economic, social and environmental) that arise from the depletion of the ecosystem services caused by excess loss of nutrients from farmland. In other words, the polluter does not pay the full cost associated with the pollution they produce and instead, where there is an economic cost associated with the remediation of the pollution, it is often the wider community that pays the price by means of government instigated remediation funded by public taxes.

This article examines the approach being taken to remediate diffuse pollution from agricultural sources in order to improve water quality in the Te Arawa lakes in the Bay of 
Published as: Abell, J. M., Hamilton, D. P. \& Paterson, J. (2011) Reducing the external environmental costs of pastoral farming in New Zealand: experiences from the Te Arawa lakes, Rotorua. Australasian Journal of

Environmental Management, 18 (3), 139-154. Available at: http://dx.doi.org/10.1080/14486563.2011.591520

Plenty region of New Zealand. It discusses some of the major (and often expensive) actions that now have to be taken to improve the water quality of several of the lakes. Water quality in the lakes has declined due to decades of excess nutrient input from sources that include, amongst others, agricultural activities. Options for future lake management policy are discussed with reference to how farming in this region, and throughout New Zealand, might become more sustainable by internalising its environmental costs.

\section{Case study: the Te Arawa lakes}

\section{National policy context}

To provide background to the regional case study, it is useful to first consider the national policy context. Following a major change in the early-mid 1980s, New Zealand farmers have operated in a competitive system characterised by a lack of subsidies (MacLeod \& Moller 2006). There is no formal link between central government and the agricultural sector (e.g. unlike Europe) and regulation of agri-environmental performance is principally the role of regional councils, which vary widely in their capacity and commitment to enforcement (Jay 2007). Under the Resource Management Act 1991, regional and unitary councils are also responsible for managing water quality, and guidance on this issue was long lacking at the national level. This situation recently changed with a National Policy Statement (NPS) for Freshwater Management in May 2011 (New Zealand Government 2011). The NPS reflects recommendations made following an extensive 'collaborative governance' process undertaken by an independent group which engaged widely with stakeholders (Land and Water Forum 2010). In particular, the NPS requires councils to safeguard freshwater ecosystems by establishing and observing limits relating to water quality and flows (Policies A1-3, B1-2). The NPS also explicitly recognises the need to consider diffuse pollution in spatial plans (Policy A4) and mandates integrated catchment management that considers downstream water resources (Policy C1-2).

\section{Regional overview}

The Te Arawa lakes are situated on the central volcanic plateau in the Bay of Plenty region of New Zealand's North Island (Figure 2). They are highly valued by the Te Arawa people who have a cultural relationship with the lakes and are the legal owners of the lake beds after Te 
Published as: Abell, J. M., Hamilton, D. P. \& Paterson, J. (2011) Reducing the external environmental costs of pastoral farming in New Zealand: experiences from the Te Arawa lakes, Rotorua. Australasian Journal of Environmental Management, 18 (3), 139-154. Available at: http://dx.doi.org/10.1080/14486563.2011.591520

Arawa signed a Deed of Settlement with the Crown in 2004. The iconic lakes are also valued for their natural beauty and for recreational activities such as trout fishing which attract tourists to the region.

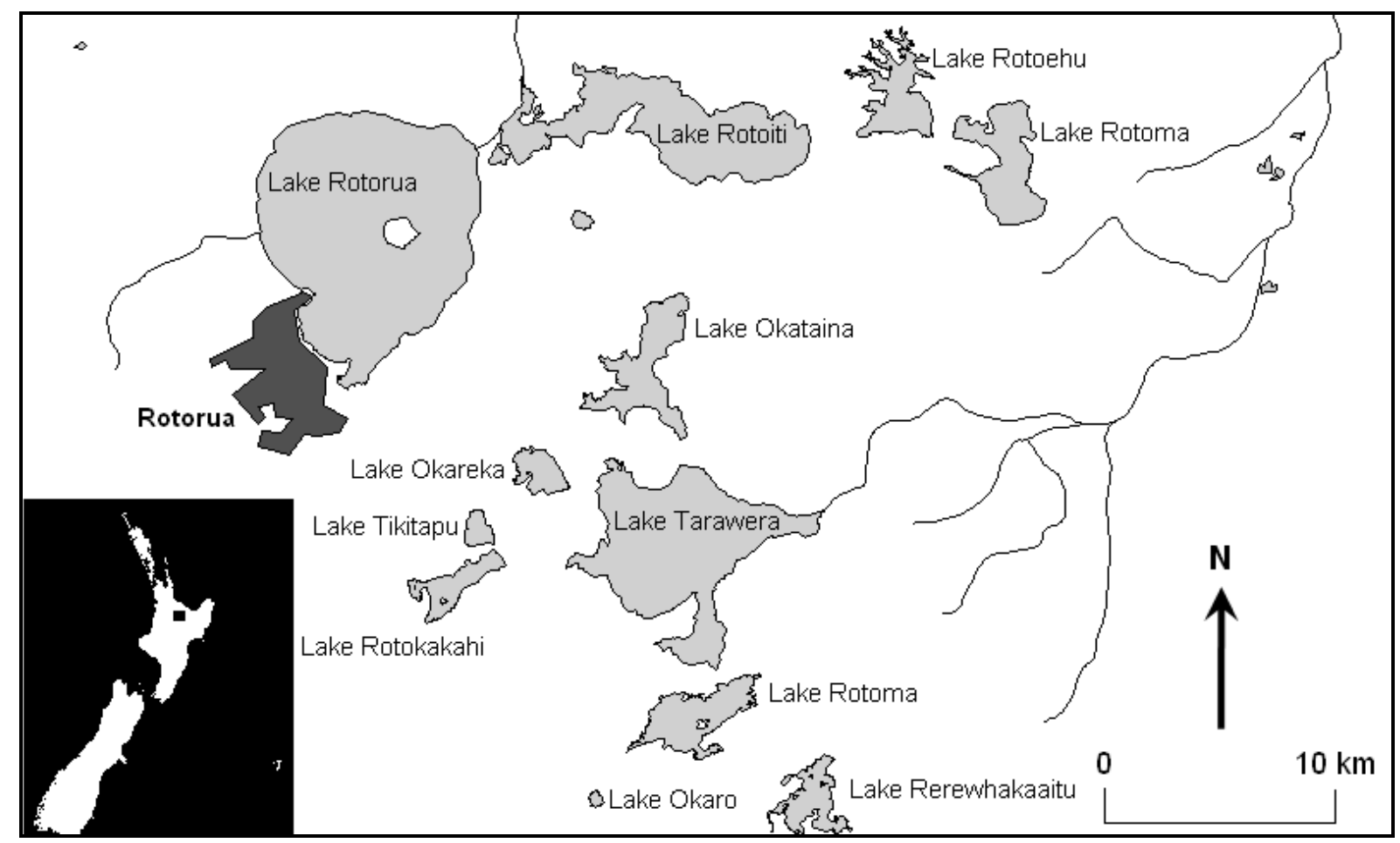

Figure 2 The twelve major Te Arawa lakes in the Bay of Plenty region of New Zealand

\section{Deteriorating water quality}

Water quality in several of the lakes has declined over the last $30-50$ years due to excess nutrient inputs associated with development in the lakes' catchments (Hamilton 2003). The main sources of nutrients are farming activities, soil erosion, septic tanks and community sewerage schemes (PCE 2006), although natural geological sources of phosphorus are also significant in some catchments (GNS 2005). Treated sewage was historically discharged into the largest lake, Lake Rotorua, until 1991 (Burns et al. 1997); however, this direct discharge ceased following construction of the Rotorua City sewage treatment system. Since then, further works have been undertaken, or are currently underway, to improve sewage treatment and reduce reliance on septic tanks to minimise nutrient loads from these sources. By contrast, nutrient loads (particularly nitrogen) from farmland have increased in several catchments in response to an increased intensity of agricultural production. For example, nitrate concentrations in streams flowing into Lake Rotorua increased steadily between 1968 and 
Published as: Abell, J. M., Hamilton, D. P. \& Paterson, J. (2011) Reducing the external environmental costs of pastoral farming in New Zealand: experiences from the Te Arawa lakes, Rotorua. Australasian Journal of Environmental Management, 18 (3), 139-154. Available at: http://dx.doi.org/10.1080/14486563.2011.591520

2002 as a result of greater export from pasture (NIWA 2003), which occupies $45 \%$ of the catchment. This source is now responsible for $75 \%$ of the nitrogen load and $46 \%$ of the phosphorus load to the lake each year (PCE 2006).

Table 1 provides a summary of the twelve major lakes. Water quality is assessed using a Trophic Level Index (TLI) (calculated from measurements of lake nutrients, chlorophyll $a$ and clarity) and an Action Plan development process is triggered when water quality is below established targets (see Burns et al. 1999; 2005; 2009). Action plans are non-statutory documents drawn up in consultation with lake stakeholders to set nutrient reduction targets and establish catchment management actions for specific lakes, often closely linked to the TLI as a performance measure (Table 1). A major complication to lake restoration efforts is the issue of groundwater lags which delay the effects of nutrient loads arising from presentday land use. Water that enters the groundwater in some catchments today has been calculated to take up to 170 years to reach the lake (GNS 2005). This lag is further compounded in some lakes by the process of internal loading which results in nutrients that have accumulated in the lake bed being periodically released back into the water column during periods of de-oxygenation (Burger et al. 2008). In shallower, eutrophic lakes these sources can even dominate over external loads. 
Published as: Abell, J. M., Hamilton, D. P. \& Paterson, J. (2011) Reducing the external environmental costs of pastoral farming in New Zealand: experiences from the Te Arawa lakes, Rotorua. Australasian Journal of Environmental Management, 18 (3), 139-154. Available at: http://dx.doi.org/10.1080/14486563.2011.591520

Table 1 Summary of the twelve major Te Arawa lakes. Data from Burns et al. (2009) and BOPRC et al. (2010)

\begin{tabular}{|c|c|c|c|c|c|}
\hline Lake & $\begin{array}{c}\text { Lake area } \\
\text { (ha) }\end{array}$ & $\begin{array}{c}\text { Max } \\
\operatorname{depth}(\mathrm{m})\end{array}$ & Trophic state* & $\begin{array}{l}\text { Long term trend } \\
\text { in water quality } \\
\text { over } 16-20 \text { years }\end{array}$ & Action Plan status \\
\hline Okataina & 1,173 & 78.5 & Oligotrophic & No change & $\begin{array}{l}\text { Process not yet } \\
\text { underway }\end{array}$ \\
\hline Rotoma & 1,112 & 83.0 & Oligotrophic & $\begin{array}{l}\text { Definite } \\
\text { degradation }\end{array}$ & Operational \\
\hline Tarawera & 4,115 & 87.5 & Oligotrophic & No change & Process underway \\
\hline Tikitapu & 144 & 27.5 & Oligotrophic & $\begin{array}{l}\text { Possible } \\
\text { degradation }\end{array}$ & Process underway \\
\hline Okareka & 334 & 33.5 & Mesotrophic & No change & Operational \\
\hline Rerewhakaaitu & 517 & 15.8 & Mesotrophic & No change & Process underway \\
\hline Rotokakahi & 433 & 32.0 & Mesotrophic & No data & $\begin{array}{l}\text { Process not yet } \\
\text { underway }\end{array}$ \\
\hline Rotoiti & 3,370 & 124.0 & Mesotrophic & $\begin{array}{l}\text { No overall change } \\
\text { but definite } \\
\text { improvement since } \\
2003\end{array}$ & Proposed \\
\hline Rotomahana & 902 & 125.0 & Mesotrophic & No change & $\begin{array}{l}\text { Process not yet } \\
\text { underway }\end{array}$ \\
\hline Rotoehu & 790 & 13.5 & Eutrophic & $\begin{array}{l}\text { Degraded, no } \\
\text { change }\end{array}$ & Operational \\
\hline Rotorua & 8,047 & 44.8 & Eutrophic & $\begin{array}{l}\text { Degraded, no } \\
\text { change }\end{array}$ & Proposed \\
\hline Okaro & 30 & 18.0 & Supertrophic & $\begin{array}{l}\text { Definite } \\
\text { improvement }\end{array}$ & Operational \\
\hline
\end{tabular}

*Trophic state refers to the primary productivity of a water body. It can range from oligotrophic (low) to supertrophic (very high). Perceived water quality typically declines with increasing trophic state.

\section{Lake restoration: actions}

Tables 2 and 3 summarise the lake restoration actions included in the Te Arawa Lake Action Plans, as well as additional actions that have been considered to remediate the impact of nutrient pollution on the lakes. Actions have been separated into two categories: those that are lake-based to reduce in-lake nutrients (Table 2) and those that are catchment-based to reduce external nutrient loads (Table 3 ). 
Published as: Abell, J. M., Hamilton, D. P. \& Paterson, J. (2011) Reducing the external environmental costs of pastoral farming in New Zealand: experiences from the Te Arawa lakes, Rotorua. Australasian Journal of Environmental Management, 18 (3), 139-154. Available at: http://dx.doi.org/10.1080/14486563.2011.591520

\section{Table 2 Lake based actions to reduce in-lake nutrient loads}

\begin{tabular}{|c|c|c|}
\hline $\begin{array}{l}\text { Lake restoration } \\
\text { action }\end{array}$ & Status & Summary \\
\hline $\begin{array}{l}\text { Diversion of } \\
\text { nutrient-rich inflows }\end{array}$ & $\begin{array}{l}\text { Undertaken in Lake } \\
\text { Rotoiti (Ohau Channel } \\
\text { construction). } \\
\text { Under consideration for } \\
\text { the Hamurana Stream } \\
\text { which enters Lake } \\
\text { Rotorua. }\end{array}$ & $\begin{array}{l}\text { Reduces nutrient inputs to the lake. May adversely affect water } \\
\text { bodies downstream. }\end{array}$ \\
\hline Dredging & $\begin{array}{l}\text { Lakes Okareka, Rotorua, } \\
\text { Rotoiti, Rotoehu and } \\
\text { Tarawera have been } \\
\text { identified as potentially } \\
\text { suitable candidate lakes } \\
\text { (A \& E Consultants } \\
\text { 2007). }\end{array}$ & $\begin{array}{l}\text { Removes nutrients from the lake bed, reducing cycling through } \\
\text { and from the sediments. } \\
\text { A recognised method worldwide although it is expensive and a } \\
\text { major logistical undertaking. Identifying a receptor site for } \\
\text { dredged material is also difficult. }\end{array}$ \\
\hline $\begin{array}{l}\text { Sediment capping / } \\
\text { phosphorus } \\
\text { inactivation }\end{array}$ & $\begin{array}{l}\text { Undertaken in lakes } \\
\text { Okaro, Okareka and in } \\
\text { Lake Rotorua inflows. } \\
\text { Trialled in streams } \\
\text { entering Lake } \\
\text { Rerewhakaaitu }\end{array}$ & $\begin{array}{l}\text { Certain materials such as natural clay minerals can render } \\
\text { nutrients unavailable for plant growth and seal lake bed } \\
\text { sediments. A modified zeolite product successfully reduced } \\
\text { total phosphorus concentrations in Lake Okaro although } \\
\text { improvements to water quality appear to occur more slowly } \\
\text { (Özkundakci et al. 2010). }\end{array}$ \\
\hline $\begin{array}{l}\text { Hypolimnetic } \\
\text { discharge }\end{array}$ & $\begin{array}{l}\text { Previously considered } \\
\text { for Lake Okareka. }\end{array}$ & $\begin{array}{l}\text { Nutrient-rich water could be removed from the bottom layers } \\
\text { while a lake is stratified and oxygen near the lake bed is } \\
\text { depleted. }\end{array}$ \\
\hline Biomanipulation & $\begin{array}{l}\text { Previously considered } \\
\text { for all lakes. }\end{array}$ & $\begin{array}{l}\text { Organisms such as the freshwater mussel (Hyridella menziesii) } \\
\text { can assimilate nutrients or consume algae. The efficacy and the } \\
\text { potential for adverse ecological impacts is uncertain (NIWA } \\
2007 \text { ). }\end{array}$ \\
\hline $\begin{array}{l}\text { Oxygenation/ } \\
\text { destratification }\end{array}$ & $\begin{array}{l}\text { Considered for Lake } \\
\text { Rotoiti and under } \\
\text { consideration for Lake } \\
\text { Rotoehu (BOPRC et al. } \\
\text { 2010). }\end{array}$ & $\begin{array}{l}\text { Delivering oxygen directly to the bottom waters of a lake can } \\
\text { prevent oxygen depletion and associated nutrient release from } \\
\text { bottom sediments. Aeration can also be used to disrupt lake } \\
\text { stratification and prevent the formation of oxygen-depleted } \\
\text { bottom waters. }\end{array}$ \\
\hline Weed harvesting & $\begin{array}{l}\text { Undertaken in lakes } \\
\text { Rotoehu and Rotoiti. }\end{array}$ & $\begin{array}{l}\text { Nutrients can be removed from lakes by harvesting aquatic } \\
\text { plants such as the invasive macrophyte hornwort } \\
\text { (Ceratophyllum demersum). }\end{array}$ \\
\hline
\end{tabular}


Published as: Abell, J. M., Hamilton, D. P. \& Paterson, J. (2011) Reducing the external environmental costs of pastoral farming in New Zealand: experiences from the Te Arawa lakes, Rotorua. Australasian Journal of Environmental Management, 18 (3), 139-154. Available at: http://dx.doi.org/10.1080/14486563.2011.591520

\section{Table 3 Catchment based actions to reduce external nutrient loads from farmland}

\begin{tabular}{|c|c|c|}
\hline $\begin{array}{l}\text { Lake restoration } \\
\text { action }\end{array}$ & Status & Summary \\
\hline Land use change & $\begin{array}{l}\text { The proposed Regional } \\
\text { Policy Statement } 2010 \\
\text { authorises district plans to } \\
\text { require resource consent for } \\
\text { land use change. } \\
\text { The district Ten Year Plan } \\
\text { is under review. } \\
\text { Identified in the Action } \\
\text { Plans for lakes Okareka and } \\
\text { Rotoehu (BOPRC et al. } \\
\text { 2010) and likely to be } \\
\text { important for lakes Rotorua } \\
\text { and Tarawera. }\end{array}$ & $\begin{array}{l}\text { Nutrient loss varies with land use and it is widely accepted } \\
\text { that the redesign of catchment land use has a fundamental role } \\
\text { in effecting change (Hamilton 2005; PCE 2006). } \\
\text { Nutrient loss is generally lowest from native vegetation and } \\
\text { plantation forest although this can vary depending on factors } \\
\text { such as harvesting regime (Hamilton 2005). The potential for } \\
\text { land use types to cause nitrate leaching typically follows the } \\
\text { order: forestry < sheep/beef/deer farming < arable/mixed } \\
\text { cropping < dairy farming < vegetable cropping (Menneer et } \\
\text { al. 2004). The potential for phosphorus loss is often more } \\
\text { variable, however high losses are likely to occur from land } \\
\text { receiving direct fertiliser or manure applications (McDowell } \\
\text { et al. 2005). }\end{array}$ \\
\hline $\begin{array}{l}\text { Creation of } \\
\text { riparian buffers }\end{array}$ & $\begin{array}{l}\text { Undertaken in some areas of } \\
\text { all lake catchments } \\
\text { (BOPRC et al. 2010). }\end{array}$ & $\begin{array}{l}\text { Riparian buffers are vegetated areas alongside waterbodies } \\
\text { that can reduce the inputs of nutrients by trapping particulate } \\
\text { forms of nutrients and increasing plant uptake of inorganic } \\
\text { forms. }\end{array}$ \\
\hline $\begin{array}{l}\text { Wetland } \\
\text { construction }\end{array}$ & $\begin{array}{l}\text { A } 2.3 \text { ha wetland has been } \\
\text { constructed alongside Lake } \\
\text { Okaro (BOPRC 2006). } \\
\text { Wetland construction has } \\
\text { been earmarked for the } \\
\text { catchment of Lake Rotoehu } \\
\text { where floating wetlands are } \\
\text { also being trialled (BOPRC } \\
\text { et al. 2010). }\end{array}$ & $\begin{array}{l}\text { Wetlands can trap sediment and promote nutrient removal } \\
\text { processes such as denitrification and uptake by plants. }\end{array}$ \\
\hline $\begin{array}{l}\text { Adoption of Best } \\
\text { Management } \\
\text { Practices (BMPs) } \\
\text { by farmers }\end{array}$ & $\begin{array}{l}\text { Applicable to all lakes, } \\
\text { especially those with a high } \\
\text { percentage of pastoral land. }\end{array}$ & $\begin{array}{l}\text { Suitable BMPs identified include: reduction of fertiliser use, } \\
\text { removal of cattle from paddocks over winter, better effluent } \\
\text { management and the use of nitrification inhibitors in feed and } \\
\text { on soil (Ritchie 2008; AgResearch 2010). }\end{array}$ \\
\hline $\begin{array}{l}\text { Installation of } \\
\text { denitrification } \\
\text { beds }\end{array}$ & $\begin{array}{l}\text { An } 18 \mathrm{~m}^{3} \text { bed of wood chips } \\
\text { has been installed along a } \\
10 \mathrm{~m} \text { section of a Lake } \\
\text { Rotoehu inflow. Monitoring } \\
\text { over } 13 \text { months indicated } \\
\text { that nitrate concentrations } \\
\text { were reduced by } \\
\text { approximately } 50 \% \\
\text { (Landcare Research 2008). }\end{array}$ & $\begin{array}{l}\text { Denitrification beds comprise containers or excavated areas } \\
\text { filled with a carbon source such as woodchips. They promote } \\
\text { the conversion of nitrate to di-nitrogen gas by microbes. } \\
\text { Trials elsewhere in New Zealand have shown that } \\
\text { denitrification beds can provide a low-cost solution for near } \\
\text { complete removal of nitrate from dairy shed effluent } \\
\text { (Schipper et al. 2010). Results will depend on local soil type } \\
\text { and topography. }\end{array}$ \\
\hline
\end{tabular}


Published as: Abell, J. M., Hamilton, D. P. \& Paterson, J. (2011) Reducing the external environmental costs of pastoral farming in New Zealand: experiences from the Te Arawa lakes, Rotorua. Australasian Journal of Environmental Management, 18 (3), 139-154. Available at: http://dx.doi.org/10.1080/14486563.2011.591520

\section{Lake restoration: policy}

Implementing lake restoration actions requires the right mix of policies in place to facilitate change. An array of policy instruments are either in use or have been proposed to reduce diffuse pollution from agricultural sources in the Te Arawa lakes (Figure 3).

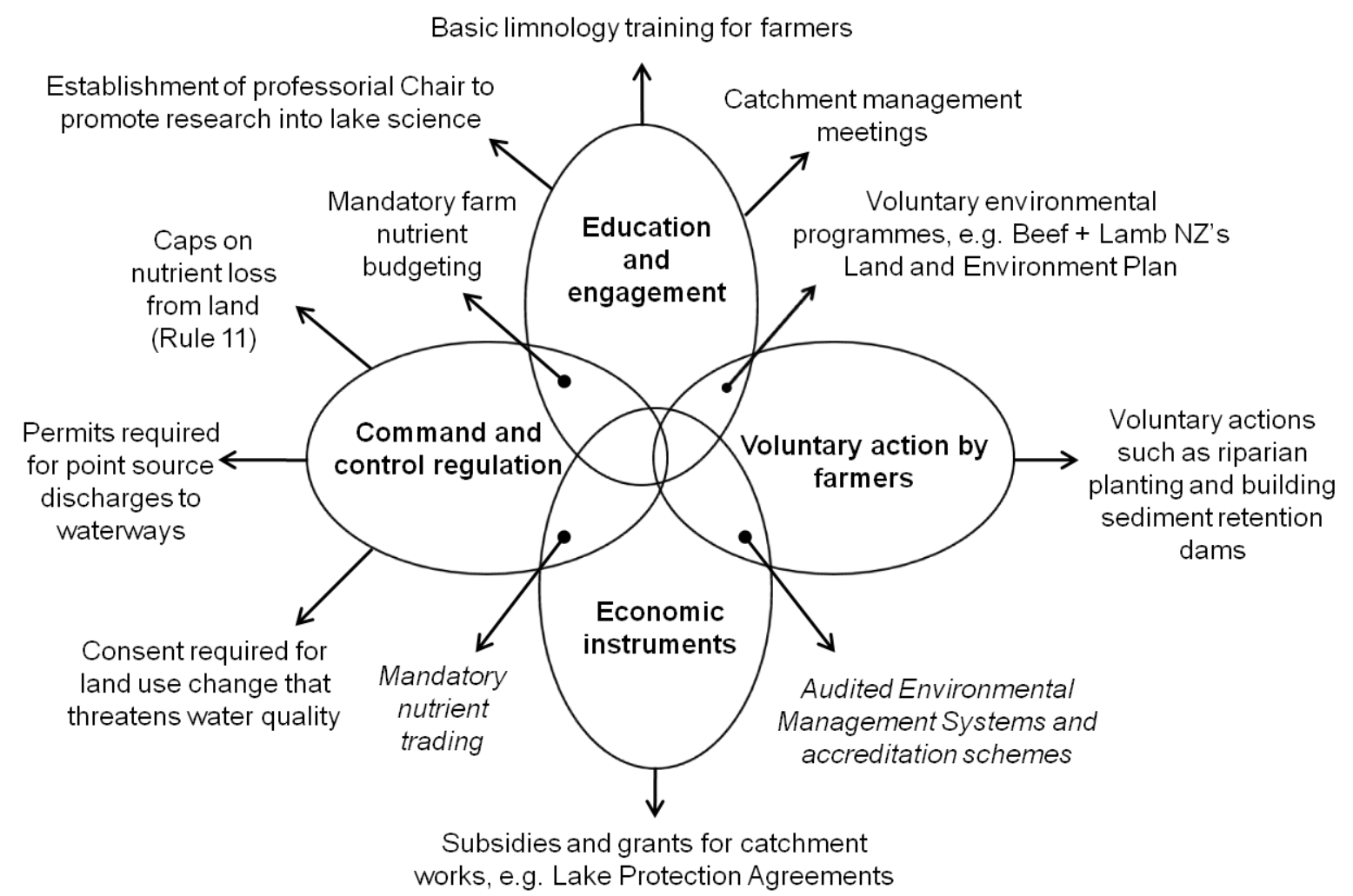

Figure 3 Policy instruments in use (bold) and proposed (italic) to reduce diffuse pollution from agricultural sources in the Te Arawa lakes

\section{Discussion}

\section{The external cost of farming}

Actions listed in Table 2 may be considered 'end of pipe' because they are designed to reduce nutrient loads once nutrients have already entered streams or lakes, rather than reducing nutrient loads at source. Experience from lake restoration programmes in the northern hemisphere has shown that physical, chemical or biological remediation techniques designed to reduce internal nutrients, but which do not simultaneously address external loads, are often of only limited success with benefits quickly eroded (Cooke et al. 2005). Improvements in 
Published as: Abell, J. M., Hamilton, D. P. \& Paterson, J. (2011) Reducing the external environmental costs of pastoral farming in New Zealand: experiences from the Te Arawa lakes, Rotorua. Australasian Journal of

Environmental Management, 18 (3), 139-154. Available at: http://dx.doi.org/10.1080/14486563.2011.591520

water quality following specific remediation actions, particularly in large lakes, may be slow and restoration failures frequently occur (Søndergaard et al. 2007). Actions such as dredging also have the potential to cause adverse environmental impacts that require mitigation and may need to be repeated periodically. Despite these shortcomings, such actions, if feasible, are now essential, in combination with catchment-based actions, if water quality improvement targets are to be achieved in the short-medium term for the most degraded lakes. This is because sediments in lakes such as Lake Rotorua have high internal stores of nutrients following decades of eutrophication (Burger et al. 2008) and therefore even complete cessation of all external nutrient loading would not achieve desired improvements in water quality.

While necessary, such actions have a high financial cost. For example, the Ohau Channel wall was completed in July 2008 and was designed to prevent water that is relatively high in nutrients from flowing from Lake Rotorua to Lake Rotoiti. The wall is estimated to have cost approximately NZ\$10 million, mostly funded by the regional council, with additional financial support coming from national government (BOPRC et al. 2010). While there are early indications that the wall has been successful in improving water quality in Lake Rotoiti (BOPRC et al. 2010), as previously noted, a large proportion of the nutrient loads entering Lake Rotorua originate from pasture, therefore the cost of mitigating the environmental impact of nutrients lost from farmland (i.e. the construction cost of the wall) is external to those groups responsible for the pollution. The same applies to the majority of the costs associated with the restoration of Lake Okaro where most of the nutrients that enter the lake also originate from agricultural sources, as pasture comprises approximately $90 \%$ of the catchment (BOPRC et al. 2010). The proposed cost of capping the sediments of Lake Okaro was NZ\$225 000 over three years, while the estimated cost of the construction of a wetland in the catchment was NZ\$520 000 (BOPRC 2006). Lake Okaro is the smallest of the Te Arawa lakes (see Table 1) and the combined cost of these two actions alone equates to approximately NZ\$25000 per hectare of lake area. In 2008, a national level Government Funding Deed provided NZ\$72.1 million towards the cost of interventions designed to improve water quality in four lakes. This pledge was a $50 \%$ contribution towards the estimated cost, with the remainder to be made up by the regional and district councils. While some of this money is directed towards addressing nutrient loss from non-agricultural sources (e.g. by enhancing community wastewater systems), a significant proportion is directed towards reducing or remediating nutrient pollution from farming. 
Published as: Abell, J. M., Hamilton, D. P. \& Paterson, J. (2011) Reducing the external environmental costs of pastoral farming in New Zealand: experiences from the Te Arawa lakes, Rotorua. Australasian Journal of

Environmental Management, 18 (3), 139-154. Available at: http://dx.doi.org/10.1080/14486563.2011.591520

\section{The national policy challenge}

While the use of public money is now essential if water quality goals in these iconic and nationally renowned lakes are to be achieved, it is clear that in the longer term, allowing water bodies in predominantly agricultural catchments to become so degraded that their restoration requires costly, public-funded engineering-based interventions is at odds with the Polluter Pays Principle (OECD, 1972) and inconsistent with the New Zealand government's stated aim of achieving the "best value for society" from the country's water resources (MfE 2009, p. 4). It is therefore desirable to develop a policy framework that promotes the implementation of actions to reduce nutrient loads at source before water quality decline occurs. Owing to the 'multi-aspect' nature of the problem (i.e., water quality decline is dependent on when, where, how and in what form nutrients loss occurs in a catchment (OECD 2007)), the successful control of diffuse pollution requires a mix of different policy instruments. Below, we discuss four broad categories of policy instrument in use around the Te Arawa lakes (Figure 3) and consider further policies that could promote a reduction of diffuse nutrient pollution from pastoral land across New Zealand.

\section{Education and engagement}

Educating farmers and landowners about nutrient pollution and basic limnology has been instrumental for gaining support and prompting voluntary action (Burns et al. 2009). Workshops and meetings have provided a forum for lake managers to engage with stakeholders and gain community 'buy-in' for the various lake remediation actions. For example, the Lakes Water Quality Society, an active community organisation that seeks to protect and restore the region's lakes, regularly holds meetings including symposia attended by water quality experts from overseas. In a wider context, an active programme of research into lake science, primarily funded by the regional council, has been integral to informing lake management policy. Central to this has been the appointment in 2002 of the professorial Chair in Lakes Management and Restoration at the University of Waikato; an appointment funded by the regional council that has fostered an adaptive management approach to lake management whereby the findings of applied research are effectively communicated to regional managers and directly inform policy. Examples of this include monitoring to assess the efficacy of sediment capping products for reducing nutrient concentrations in the lake water column (Özkundakci et al. 2010) and the use of hydrological and ecological models to help lake managers to prioritise the control of different nutrient sources (Burger et al. 2008). 
Published as: Abell, J. M., Hamilton, D. P. \& Paterson, J. (2011) Reducing the external environmental costs of pastoral farming in New Zealand: experiences from the Te Arawa lakes, Rotorua. Australasian Journal of

Environmental Management, 18 (3), 139-154. Available at: http://dx.doi.org/10.1080/14486563.2011.591520

Throughout New Zealand, further education of the farming community about nutrient management issues could encourage change. Research in Australia has shown that greater provision of training and education is at the top of a 'preference hierarchy' of policy instruments favoured by landowners (Cocklin et al. 2007). Numerous guidelines provide advice to farmers on issues such as effluent management (Dairy NZ 2011) although it remains a challenge to transfer this knowledge to farmers whose time for training events is limited. The wider establishment of farmer-led workshops supported by regional government, already being undertaken in some regions (e.g. Waikato), is one possible way to disseminate good practice. Such events need to be scheduled at times in the farming calendar when farmers are least busy although even well planned events will not reach those who are resistant to change. In addition to informing farmers, programmes that educate the public about the causes of water quality decline could prompt communities to collaboratively take action to address pollution sources. There is evidence of growing concern amongst the New Zealand public about the state of the nation's freshwaters (Land and Water Forum 2010). If the sight of livestock routinely standing in a stream were to have the same connotations as, for example, the sight of a smoke stack at a fossil fuel power station, then the rate of action could increase in response to an altered social 'license to operate' for the pastoral farming industry. Within the dairy industry, there is awareness of the importance of maintaining public support (NZFW 2011) and therefore a consolidated public outcry about farm environmental performance is likely to elicit a collective response from industry. Further analysis of the adverse economic impact of poor water quality on New Zealand's tourism brand could also provide further incentive.

\section{Voluntary Action}

Voluntary action by farmers has a role in reducing nutrient losses, especially given that lake Action Plans are non-statutory documents that require co-operation from land users. Throughout New Zealand, the use of environmental farm plans provides a tool for farmers to strategically address the environmental impact of their activities, however, the use of such plans has so far been limited and fragmented (Manderson et al. 2007). At the industry level, there is a growing recognition by the agricultural sector of a need to demonstrate credible stewardship (Dairy NZ 2009), as demonstrated by the development of the Dairying and Clean Streams Accord in 2003. The Accord contains quantified performance targets that have been jointly agreed upon by dairy industry representatives and the government to meet the goal of 
Published as: Abell, J. M., Hamilton, D. P. \& Paterson, J. (2011) Reducing the external environmental costs of pastoral farming in New Zealand: experiences from the Te Arawa lakes, Rotorua. Australasian Journal of

Environmental Management, 18 (3), 139-154. Available at: http://dx.doi.org/10.1080/14486563.2011.591520

achieving "clean, healthy water" in dairying areas (Fonterra et al. 2003, p. 1). Doubt has been raised, however, regarding the success of the industry to meet its commitments (Deans and Hackwell 2008) and a review of progress towards meeting Accord targets found that the level of full compliance had dropped by $4 \%$ in 2008/2009 from the previous year, while the level of significant non-compliance had increased to an "unacceptable" level (Fonterra et al. 2010, p. 6). It is now widely acknowledged that voluntary action alone has only limited potential to contribute towards better water quality (Land and Water Forum 2010) and this is especially true for the most polluted lake catchments where the necessary remedial actions are often extensive and financially costly.

\section{Regulation}

Command and control regulation involves setting and regulating standards based on perceived environmental limits. It is often the best instrument to use when an absolute change in behaviour is required (Roberts 2004). In the Te Arawa lakes, a risk-based approach has been taken by imposing limits on nutrient loss from properties in the catchments of the worst affected lakes. 'Rule 11' of the regional Water and Land Plan (BOPRC 2008) prohibits loss of nutrients from pastoral land at rates greater than an individual farm benchmark level. A common difficulty, however, in applying regulation to control nutrient loss from farmland is that the diffuse nature of the pollution means that nutrient losses are hard to measure and attribute to specific individuals (Barnes et al. 2009). In this case, the solution is to use farmscale modelling software $\left(\right.$ Overseer $\left.{ }^{\circledR}\right)$ that allows nutrient losses from properties to be estimated and benchmarked (Burns et al. 2009). Around Lake Rotorua, catchment-based nutrient models have been coupled with models of lake processes to simulate possible future land use scenarios, thereby informing spatial planning for meeting water quality goals (NIWA 2011).

At the national scale, the recent NPS for Freshwater Management will now require regional councils to set freshwater quality limits (New Zealand Government 2011). This represents a major addition to national policy but defining and regulating the new limits poses a challenge to councils. In this respect, knowledge gained in Europe during work to achieve compliance with the Water Framework Directive (EC 2000) could provide guidance, for example, regarding identifying reference sites with high ecological integrity from which limits can be based. Once established, planning controls are likely to be an important tool for councils to enforce limits and a risk-based approach to enforcement has efficiency advantages. An 
Published as: Abell, J. M., Hamilton, D. P. \& Paterson, J. (2011) Reducing the external environmental costs of pastoral farming in New Zealand: experiences from the Te Arawa lakes, Rotorua. Australasian Journal of

Environmental Management, 18 (3), 139-154. Available at: http://dx.doi.org/10.1080/14486563.2011.591520

example of such an approach in practice is the EU Nitrates Directive which requires Member States to identify 'Nitrate Vulnerable Zones' where farmers are required to limit the application of nutrients (170 kg/ha of nitrogen) and adhere to certain practices (EC 1991). Although extensive work would be required to identify 'at risk' areas throughout New Zealand, this work is already underway in many areas on a regional basis and, as described above, numerous modelling tools have been developed to estimate nutrient loss for catchments (McDowell et al. 2005). Use of such models to calculate pollutant Total Maximum Daily Load (TMDL), a concept used in the U.S.A. (EPA 1991), could also support compliance with introduced standards. Definitions such as TMDLs could help catchment managers to focus on critical source areas of pollution and prompt debate about relative contributions of polluters to a defined TMDL.

\section{Economic Instruments}

Finally, economic instruments are a form of policy with potentially the greatest scope for further adoption. So called 'market based instruments' (MBIs) are often regarded as more efficient than regulation, allowing environmental objectives to be achieved more cost effectively than with regulation alone (Lubbe-Wolff 2001). This will often be the case for diffuse pollution, as large polluters can often achieve greater nutrient reductions at a lower average cost than others. Subsidies for catchment works so far represent the main use of this instrument around the Te Arawa lakes with grants being made available to encourage landowners to undertake fencing and planting in retirement areas and riparian margins. Lake Protection Agreements have provided a mechanism to administer subsidies and bind landowners to collaboratively agreed reductions in nutrient loss from their land. A more radical MBI is nutrient trading which has been proposed for use in the Lake Rotorua catchment (MOTU 2008) and a form of which is already successfully operating at Lake Taupo in the Waikato region (WRC 2010). Nutrient trading involves assigning nutrient loss allowances to individual properties that are in proportion to a set nutrient-loss benchmark, to achieve an established nutrient reduction target. Modelling tools can then be used to estimate actual nutrient loss, and tradable permits required to be purchased to cover excessive losses. Although there are precedents, nutrient trading is a novel tool and its implementation would require extensive communication with stakeholders, not to mention a progressive attitude from enforcement agencies and politicians. It is unlikely to be feasible to implement at the national scale due to the extensive amount of catchment information required (e.g. 
Published as: Abell, J. M., Hamilton, D. P. \& Paterson, J. (2011) Reducing the external environmental costs of pastoral farming in New Zealand: experiences from the Te Arawa lakes, Rotorua. Australasian Journal of

Environmental Management, 18 (3), 139-154. Available at: http://dx.doi.org/10.1080/14486563.2011.591520

quantification of groundwater flows and nutrient reduction targets) and likely administrative work involved. Nevertheless, nutrient trading has been shown to be compatible with the existing legislative framework (Rive et al. 2008) and, given its successful adoption in Taupo and potential to result in almost immediate realisation of nutrient reduction targets, nutrient trading warrants serious consideration as a tool to control pollution in New Zealand's most sensitive and iconic catchments. Other MBIs that could also hold promise include environmental taxes (e.g. on fertilisers) and eco-labelling schemes. The latter instrument would involve consumers paying a premium for agricultural produce that has been certified as originating from farms that adhere to an audited Environment Management System (EMS), thereby providing an economic incentive for farmers to make positive changes. The success of such an initiative would be contingent on undertaking robust analysis to determine the requisite market-drivers to promote uptake; research in Australia has shown that dairy farmers who trialled the adoption of a simplified EMS were reluctant to continue their involvement without external facilitation or the threat of increased regulatory measures (Cary \& Roberts 2011). Additionally, there may be greater potential for initiatives that are designed primarily to reduce national greenhouse gas emissions to also contribute towards reducing nutrient export by promoting positive land use change. Incentive for 'carbon farming' is set to increase when obligations for agricultural participants under the New Zealand Emissions Trading Scheme come into force in 2015 (Climate Change Response (Moderated Emissions Trading) Amendment Bill, 2009). Therefore, a target for land managers is to ensure that opportunities are sought to enhance water quality whilst concurrently reducing farmers' carbon liabilities. For example, afforestation resulting from an Afforestation Grant Scheme or the Permanent Forest Sink Initiative could be targeted at critical nutrient source areas in catchments to support combined water quality and climate change mitigation goals. Lastly, a more radical MBI proposal is to pay farmers for the provision of ecosystem services, as suggested by Baskaran (2009) who showed that New Zealanders may be willing to pay approximately NZ\$39 per year in additional taxes if farmers were to reduce nitrogen loss to waterways by $30 \%$. Such a policy potentially represents the ultimate step in recognising the importance of the non-economic services provided by farmland; however, its use would first require significant further research and would represent a major shift in policy. 
Published as: Abell, J. M., Hamilton, D. P. \& Paterson, J. (2011) Reducing the external environmental costs of pastoral farming in New Zealand: experiences from the Te Arawa lakes, Rotorua. Australasian Journal of

Environmental Management, 18 (3), 139-154. Available at: http://dx.doi.org/10.1080/14486563.2011.591520

\section{Conclusion}

The emphasis of New Zealand's pastoral industries on maintaining international competitiveness has created drivers for 'stand alone' efficiencies that have led many farmers to intensify their practices in good faith, seeking profitability through production increases. The disadvantage of this focus on production has been a decrease in the overall environmental sustainability of farming and, as a result, many agricultural catchments now fail to meet community expectations regarding water quality goals. Decades of high nutrient inputs from human sources to the Te Arawa lakes have meant that lake managers now have to resort to large-scale and expensive engineering-based remediation methods in some instances to reduce internal nutrient loads in the worst affected lakes. Such actions are only the first step towards improving water quality and they are being supported by a range of further actions implemented using a mix of policy instruments to reduce nutrient loads in the long term. Initial signs are that the comprehensive remediation programme is working for some of the lakes but communities need to be realistic about the time scales involved and difficult decisions remain to be made if water quality goals for the worst affected lakes are to be achieved. Until very recently, there has been an absence of policy at the national scale to discourage similar situations in catchments elsewhere and, where policies that could effect change do exist at higher levels, there has been reticence by some politicians to use these policies to achieve water quality goals (e.g. by using the Resource Management Act to impose land use controls). Recent issue of the first NPS for Freshwater Management has contributed towards addressing this policy gap. By requiring freshwater quality limits to be set and explicitly recognising the importance of protecting ecosystem services, the NPS represents an environmentally progressive step for water governance in New Zealand. The extent of regional implementation of the NPS has, however, yet to be seen, and without a comprehensive and integrative shift towards sustainable land use practices, it is likely that water quality decline will continue for the foreseeable future, leaving more communities faced with making difficult decisions about remediating polluted lakes in their region.

\section{Acknowledgements}

Jonathan Abell is funded by a Commonwealth Scholarship and a Bay of Plenty Regional Council study award. We acknowledge funding from the Foundation of Research, Science 
Published as: Abell, J. M., Hamilton, D. P. \& Paterson, J. (2011) Reducing the external environmental costs of pastoral farming in New Zealand: experiences from the Te Arawa lakes, Rotorua. Australasian Journal of Environmental Management, 18 (3), 139-154. Available at: http://dx.doi.org/10.1080/14486563.2011.591520

and Technology (Lake Biodiversity Restoration contract UOWX0505) and thank Andy Bruere, John McIntosh, Deniz Özkundakci and two anonymous reviewers for their helpful comments. The views expressed are the authors' own. 
Published as: Abell, J. M., Hamilton, D. P. \& Paterson, J. (2011) Reducing the external environmental costs of pastoral farming in New Zealand: experiences from the Te Arawa lakes, Rotorua. Australasian Journal of Environmental Management, 18 (3), 139-154. Available at: http://dx.doi.org/10.1080/14486563.2011.591520

\section{References}

A \& E Consultants 2007, Summary report on possible dredging of lakes in the Rotorua district, Report prepared for Bay of Plenty Regional Council.

Abell JM, Özkundakci, D, Hamilton, DP \& Miller, SD 2011, 'Relationships between land use and nitrogen and phosphorus in New Zealand lakes', Marine and Freshwater Research, vol. 62, no. 2, pp. 162-175.

AgResearch 2010, The efficacy of strategies to mitigate the loss of phosphorus from pastoral land use in the catchment of Lake Rotorua, Report prepared for Bay of Plenty Regional Council.

Barnes, AP, Moran, D \& Topp, K 2009, 'The scope for regulatory incentives to encourage increased efficiency of input use by farmers', Journal of Environmental Management, vol. 90, no.2, pp. 808-814.

Baskaran, R, Cullen, R \& Takatsuka, Y 2009, 'Estimating the value of agricultural ecosystem services: a case study of New Zealand pastoral farming', Australasian Journal of Environmental Management, vol. 16, no. 2, pp. 103-112.

BOPRC (Bay of Plenty Regional Council) 2006, Lake Okaro action plan. Whakatane, New Zealand.

BOPRC (Bay of Plenty Regional Council) 2008, Bay of Plenty regional water and land plan, Whakatane, New Zealand. 
Published as: Abell, J. M., Hamilton, D. P. \& Paterson, J. (2011) Reducing the external environmental costs of pastoral farming in New Zealand: experiences from the Te Arawa lakes, Rotorua. Australasian Journal of

Environmental Management, 18 (3), 139-154. Available at: http://dx.doi.org/10.1080/14486563.2011.591520

BOPRC (Bay of Plenty Regional Council), Rotorua District Council \& Te Arawa Lakes Trust 2010, State of the Rotorua/Te Arawa Lakes 2009-2010.

Burger, DF, Hamilton, DP \& Pilditch, CA 2008, 'Modelling the relative importance of internal and external nutrient loads on water column nutrient concentrations and phytoplankton biomass in a shallow polymictic lake', Ecological Modelling, vol. 211, no. 3-4, pp. 411-423.

Burns, N, Deely, J, Hall, J \& Safi, K 1997, 'Comparing past and present trophic states of seven Central Volcanic Plateau lakes, New Zealand', New Zealand Journal of Marine and Freshwater Research, vol. 31, no. 1, pp. 71-87.

Burns, N, Rutherford, JC \& Clayton, JS 1999, 'A monitoring and classification system for New Zealand lakes and reservoirs', Journal of Lakes Research \& Management, vol. 15, no. 4, pp. $225-271$.

Burns, N, McIntosh, J \& Scholes, P 2005, 'Strategies for managing the lakes of the Rotorua district, New Zealand', Lake and Reservoir Management, vol. 21, no. 1, pp. 61-72.

Burns, N, McIntosh, J \& Scholes, P 2009, 'Managing the lakes of the Rotorua district, New Zealand', Lake and Reservoir Management, vol. 25, no. 3, pp. 284-296.

Cary, J \& Roberts, A 2011, 'The limitations of environmental management systems in Australian agriculture', Journal of Environmental Management, vol. 92, no. 93, pp. 878 - 885. 
Published as: Abell, J. M., Hamilton, D. P. \& Paterson, J. (2011) Reducing the external environmental costs of pastoral farming in New Zealand: experiences from the Te Arawa lakes, Rotorua. Australasian Journal of Environmental Management, 18 (3), 139-154. Available at: http://dx.doi.org/10.1080/14486563.2011.591520

Climate Change Response (Moderated Emissions Trading) Amendment Bill 2009, Subpart 2 Allocation of New Zealand units in relation to industry and agriculture, New Zealand Legislation.

Cocklin, C, Mautner, N \& Dibden, J 2007, 'Public policy, private landholders: Perspectives on policy mechanisms for sustainable land management', Journal of Environmental Management, vol. 85, no. 4, pp. 986-998.

Costanza, R, dArge, R, deGroot, R, Farber, S, Grasso, M, Hannon, B, Limburg, K, Naeem, S, ONeill, RV, Paruelo, J, Raskin, RG, Sutton, P \& vandenBelt, M 1997, 'The value of the world's ecosystem services and natural capital', Nature, vol. 387, no. 6630, pp. 253-260.

Cooke, GD, Welch, EB, Peterson, A \& Nichols, SA 2005, Restoration and management of lakes and reservoirs, Boca Raton, Florida, USA.

Dairy NZ 2009, Strategy for New Zealand dairy farming 2009/2020, Dairy NZ Limited.

Dairy NZ 2011, Farm dairy effluent (FDE) design code of practice, Dairy NZ Limited.

Deans, N \& Hackwell, K 2008. Dairying and declining water quality, Report published by Forest \& Bird, Fish \& Game, New Zealand.

EC (European Commission) 1991, 'Directive 91/676/EEC of 12 December 1991 concerning the protection of waters against pollution caused by nitrates from agricultural sources', Official Journal of the European Union, L. 375, pp. 1-8 
Published as: Abell, J. M., Hamilton, D. P. \& Paterson, J. (2011) Reducing the external environmental costs of pastoral farming in New Zealand: experiences from the Te Arawa lakes, Rotorua. Australasian Journal of Environmental Management, 18 (3), 139-154. Available at: http://dx.doi.org/10.1080/14486563.2011.591520

EC (European Commission) 2000, 'Directive 2000/60/EC of the European Parliament and of the Council establishing a framework for the Community action in the field of water policy', Official Journal of the European Union, L. 327, pp. 1-72.

EPA (Environmental Protection Authority) 1991, Guidance for water quality-based decisions: The TMDL process, viewed $14 \quad$ March 2011, http://water.epa.gov/lawsregs/lawsguidance/cwa/tmdl/decisions_index.cfm

Fonterra, Ministry for the Environment, Ministry of Agriculture \& Local Government NZ 2003, Dairying and Clean Streams Accord.

Fonterra, Ministry for the Environment, Ministry of Agriculture \& Local Government NZ 2010, Dairying and Clean Streams Accord: Snapshot of progress 2008/2009.

GNS (Geological and Nuclear Sciences) 2005, Groundwater age and chemistry, and future nutrient loads for selected Rotorua Lakes' catchments, Report prepared for Bay of Plenty Regional Council.

Hamilton DP 2003, 'An historical and contemporary review of water quality in the Rotorua lakes', in N Miller (ed.), Proceedings of the Rotorua Lakes 2003 Symposium: Practical management for good lake water quality, Rotorua, pp. 3-15.

Hamilton DP 2005, 'Land use impacts on nutrient export in the Central Volcanic Plateau, North Island', New Zealand Journal of Forestry, vol. 49, no. 4, pp. 27-31.

Hardin, G 1968, 'The tragedy of the commons', Science, vol. 162, no. 3859, pp. 1243-1248. 
Published as: Abell, J. M., Hamilton, D. P. \& Paterson, J. (2011) Reducing the external environmental costs of pastoral farming in New Zealand: experiences from the Te Arawa lakes, Rotorua. Australasian Journal of Environmental Management, 18 (3), 139-154. Available at: http://dx.doi.org/10.1080/14486563.2011.591520

Jay, M 2007, 'The political economy of a productivist agriculture: New Zealand dairy discourses', Food Policy, vol. 32, no. 2, pp. 266-279.

Jeppesen, E, Kronvang, B, Olesen, J, Audet, J, Søndergaard, M, Hoffmann, C, Andersen, H, Lauridsen, T, Liboriussen, L, Larsen, S, Beklioglu, M, Meerhoff, M, Özen, A \& Özkan, K 2011, 'Climate change effects on nitrogen loading from cultivated catchments in Europe: implications for nitrogen retention, ecological state of lakes and adaptation', Hydrobiologia, vol. 663 , no. 1, pp. 1-21.

Land and Water Forum 2010, Report of the Land and Water Forum: A fresh start for fresh Water.

Landcare Research 2008, Denitrification in a Rotoehu stream, $2^{\text {nd }}$ installation. Report prepared for Bay of Plenty Regional Council.

Lant, CL, Ruhl, JB \& Kraft, SE 2008, 'The tragedy of ecosystem services', Bioscience, vol. 58, no. 10 , pp. $969-974$.

Lubbe-Wolff, G 2001, 'Efficient environmental legislation - on different philosophies of pollution control in Europe', Journal of Environmental Law, vol. 13, no. 1, pp. 79-87.

MacLeod, CJ \& Moller, H 2006, 'Intensification and diversification of New Zealand agriculture since 1960: An evaluation of current indicators of land use change', Agriculture, Ecosystems and Environment, vol. 115, no. 1-4, pp. 201-218. 
Published as: Abell, J. M., Hamilton, D. P. \& Paterson, J. (2011) Reducing the external environmental costs of pastoral farming in New Zealand: experiences from the Te Arawa lakes, Rotorua. Australasian Journal of Environmental Management, 18 (3), 139-154. Available at: http://dx.doi.org/10.1080/14486563.2011.591520

Manderson, AK, Mackay, AD \& Palmer, AP 2007, 'Environmental whole farm management plans: Their character, diversity, and use as agri-environmental indicators in New Zealand', Journal of Environmental Management, vol. 82, no. 3, pp. 319-331.

McDowell, RW, Monaghan, RM \& Wheeler, D 2005, 'Modelling phosphorus losses from pastoral farming systems in New Zealand', New Zealand Journal of Agricultural Research, vol. 48, no.1, pp. 131-141.

McDowell, RW \& Wilcock, RJ 2008, 'Water quality and the effects of different pastoral animals', New Zealand Vetinary Journal, vol. 56, no. 6, pp. 289-296.

Menneer, JC, Ledgard, SF \& Gillingham, AG 2004, Land use impacts on nitrogen and phosphorus loss and management options for intervention, Report prepared for Bay of Plenty Regional Council.

MfE (Ministry for the Environment) 2009, The new start for fresh water cabinet paper, Wellington, New Zealand.

MOTU 2008, Nutrient trading in Lake Rotorua: Overview of a prototype system, Wellington, New Zealand.

New Zealand Government 2011, The national policy statement for freshwater management, Wellington, New Zealand.

New Zealand Treasury 2009, New Zealand economic and financial overview 2009, Wellington, New Zealand. 
Published as: Abell, J. M., Hamilton, D. P. \& Paterson, J. (2011) Reducing the external environmental costs of pastoral farming in New Zealand: experiences from the Te Arawa lakes, Rotorua. Australasian Journal of Environmental Management, 18 (3), 139-154. Available at: http://dx.doi.org/10.1080/14486563.2011.591520

NZFM (The New Zealand Farmers Weekly) 2011, 'Dairying needs public on side', viewed 06 March 2011, http://www.nzfarmersweekly.co.nz/article/8724.html

NIWA (National Institute of Water and Atmospheric Research) 2003, Lake Rotorua nutrient load targets, Report prepared for Bay of Plenty Regional Council.

NIWA (National Institute of Water and Atmospheric Research) 2007, Review of the potential for the biomanipulation of phytoplankton by freshwater mussels (kakahi) in the Te Arawa Lakes, Report prepared for Bay of Plenty Regional Council.

NIWA (National Institute of Water and Atmospheric Research) 2011, Prediction of nitrogen loads to Lake Rotorua using the ROTAN model, Report prepared for Bay of Plenty Regional Council.

OECD (Organisation for Economic Co-operation and Development) 1972, Environment and economics guiding principles concerning international economic aspects of environmental policies, OECD Recommendation adopted on 26th May, 1972.

OECD (Organisation for Economic Co-operation and Development) 2007, 'Instrument mixes for environmental policy', OECD Publishing.

Özkundakci, D, Hamilton, DP \& Scholes P 2010, 'Effect of intensive catchment and in-lake restoration procedures on phosphorus concentrations in a eutrophic lake', Ecological Engineering, vol. 36, no.4, pp. 396-405. 
Published as: Abell, J. M., Hamilton, D. P. \& Paterson, J. (2011) Reducing the external environmental costs of pastoral farming in New Zealand: experiences from the Te Arawa lakes, Rotorua. Australasian Journal of Environmental Management, 18 (3), 139-154. Available at: http://dx.doi.org/10.1080/14486563.2011.591520

PCE (Parliamentary Commissioner for the Environment) 2004, Growing for good: Intensive farming, sustainability and New Zealand's environment, Wellington, New Zealand.

PCE (Parliamentary Commissioner for the Environment) 2006, Restoring the Rotorua Lakes: The ultimate endurance challenge, Wellington, New Zealand.

Ritchie, H 2008, Review of research on practices to reduce $N$ and $P$ loss from farms in the Rotorua Lakes catchments, Report prepared for the Land Use Futures Board.

Rive, V, Rogers, B \& Law, C 2008, Initial report on nutrient trading under the Resource Management Act (1991), Chapmann Tripp Barristers and Solicitors New Zealand.

Roberts, J 2004, ‘Environmental Policy’, Routledge, London, United Kingdom.

Schipper, LA, Cameron, SC \& Warneke, S 2010, 'Nitrate removal from three different effluents using large-scale denitrification beds', Ecological Engineering, vol. 36, no.11, pp. 1552-1557.

Smith, VH, Tilman, GD \& Nekola, JC 1999, 'Eutrophication: impacts of excess nutrient inputs on freshwater, marine, and terrestrial ecosystems', Environmental Pollution, vol. 100, no. $1-3$, pp. 179-196.

Søndergaard, M, Jeppesen, E, Lauridsen, TL, Skov, C, Van Nes, EH, Roijackers, R, Lammens, E \& Portielje, R 2007, 'Lake restoration: successes, failures and long-term effects', Journal of Applied Ecology, vol. 44, no.6, pp. 1095-1105. 
Published as: Abell, J. M., Hamilton, D. P. \& Paterson, J. (2011) Reducing the external environmental costs of pastoral farming in New Zealand: experiences from the Te Arawa lakes, Rotorua. Australasian Journal of Environmental Management, 18 (3), 139-154. Available at: http://dx.doi.org/10.1080/14486563.2011.591520

Statistics New Zealand 2009, Agricultural Production Statistics: Obtained from the INFOS database, viewed 16 February 2011, www.stats.govt.nz.

WRC (Waikato Regional Council) 2010 Nitrogen sourcing and trading in the Lake Taupo catchment, Hamilton, New Zealand. 